\title{
Prospects of Attaining Competitive Advantages and Removing Infrastructure Restrictions in the Republic of Tyva: Challenges of the Time
}

\author{
Anatoly Asaul \\ Department of business Economics and innovation \\ St. Petersburg State University of Architecture and Civil \\ Engineering \\ St. Petersburg, Russian Federation \\ asaul@yandex.ru \\ Yuri Levin \\ Department of regional management and national policy \\ Moscow State Institute of International Relations \\ Moscow, Russian Federation \\ levin25@mail.ru
}

\begin{abstract}
Accounting for paper considers the potential of structural transformations of the Republic of Tyva with account of the specific features of its territory in the context of the new spatial development strategy of Russia and the long-term interests of the state in the Angara-Yenisei macroregion. Its objective isdevelopment and argumentation of a new vision of the role of the state as a coordinator and regulator of the development prospects of the Republic of Tyva, necessary for the dynamic development of its entire territory and the achievement of Russia's strategic interests in the Asia-Pacific region. The paper states the lost opportunities of the Republic of Tyva due to the poor saturation of its territory with factors of production and the low level of development of the local infrastructure. It studies the main directions of the current and future development of the Republic of Tyva in the context of evaluating the effectiveness of the structural transformation policy. It is proved that the choice of the development vector of the territory of the Republic of Tyva having a large resource potential can directly influence the atmosphere of progressive growth and entrepreneurial initiative, which needs coordinating participation from the authorities. The paper gives reasons for the interdependence of the underdeveloped financial markets of the region and the investment deficit, which necessitates the implementation of state support measures. The conclusion is drawn that the systemic process of increasing the efficiency of using the resource potential and creating an attractive environment for investors in the Republic of Tyva requires greater involvement of government structures both through specific regulatory measures and using a wide range of indirect methods based on approaches to coordinate socio-cultural and economic development.
\end{abstract}

\author{
Maksim Asaul \\ Moscow, Russian Federation \\ asaul-m-a@yandex.ru \\ Vyacheslav Sevek \\ Economic faculty \\ Tuvan State University \\ Kyzyl, Russian Federation \\ vsevek@mail.ru
}

Department of Economics of automobile transport Moscow Automobile and Road State Technical University

Keywords: Angara-Yenisei macroregion, spatial development, investment climate, level of socio-cultural and economic development, human potential, national configuration of institutional elements

\section{INTRODUCTION}

Strategic goals of the state are being fulfilled on the territory of the Republic of Tyva, including dynamic development of the economy, control over the most important reserves of raw materials and the efficiency of their exploitation, the global infrastructure project of "One Belt, One Road" with the railway part of "Silk Road Economic Belt". The expansion of the trade and transport space of Russia to the East meets the interests of attaining the strategic goals of Russia in the world community [1], bring the Republic of Tyva closer to the markets of other regions of Russia and to the external markets of the Asia-Pacific region (APR), one of the main centers of development of the world economy. The spatial development strategy of the Russian Federation until 2025 focusing on the attainment of the competitive advantages of each region of the country provides for increased production potential of traditional types of economic activities as well as the development of its infrastructure space in the Republic of Tyva. 


\section{Methodological Basis OF ReSEARCH AND} ANALYSIS

The General scientific and special methods of cognition used in the research are methods of system-structural analysis, economic-statistical, logical analysis and forecasting, comparative multifactorial analysis of the problems of the region.

The methodological basis of the study was laid by the works of Russian and foreign scientists who studied the problems of sustainable development of regions, the formation of their competitive advantages, overcoming the depression of territories $[2,3,4,5,6,7]$. From their works it follows both that the issues of theory and methodology of formation of regional development strategies are certainly relevant, and the conclusions that the incompleteness of methodological developments, as well as many disparate studies of regional dynamics of socio-economic processes, make it difficult to solve problems aimed at overcoming the missed opportunities of depressed regions due to the weak saturation of their territories with factors of production and low level of development of local infrastructure. Remain insufficiently studied current issues in the realization of the potential of structural transformation of the underdeveloped region, taking into account the characteristics of its site and long-term national interests, which requires development and argument approaches a new vision of the role of the state as coordinator and regulator of the region's development prospects necessary for its sustainable development and the achievement of strategic interests of Russia.

The dynamism of the processes that characterize the problems of realization of competitive advantages in the context of removing infrastructure constraints, summarizing the results of their many years of scholarly work of the authors of this study in the field of regional economy, attracting extensive factual material determines the need to explore some of these issues in relation to current conditions taking into account essential specifics ethnic region - the Republic of Tyva.

The Republics of Tyva and Khakassia, Irkutsk Region and Krasnoyarsk Krai are interconnected in a single economic and geographical space, forming the Angara-Yenisei macroregion. The strengths of the territory of Tyva, the basis of its competitiveness are its proximity to sales markets in the AsiaPacific region, the potential of a large transport and transit capacity eventually provided by the developed trunk network, as well as a diversified economic complex and significant natural resource potential. The accelerated development of the APR countries, the implementation of Russia's geopolitical interests give foreseeable new opportunities to the economy of the Republic of Tyva. The Strategy for Spatial development of Russia,the program documents of the regional executive power state the priorities, goals, tasks, mechanisms and specific measures for the development of the Republic of Tyva.

The vulnerability of the territory of the Republic of Tyva is the substantial restrictions of its geographical accessibility due to the transport infrastructure inadequate to the modern requirements (lack of railway communication with the
Republic of Tyva, poor development of air connections and automobile network). This currently makes most contracts with external partners patently ineffective and impedes the implementation of Tyva's competitive advantages, such as its favorable location in relation to the geographically closest APR countries: Mongolia and the second world economy, China; presence of gold deposits, rich mineral resources, proven reserves of polymetallic ores. Due to the low saturation with production factors and the poor development of the transport infrastructure, the economy of the Republic of Tyva cannot, without launching appropriate development mechanisms, offer domestic and foreign consumers the products that are no less attractive in terms of price and quality in comparison with competitive products of the Siberian regions characterized by pronounced specialization, a higher level of development of processing enterprises and resource types of economic activities, balanced agrarian and industrial economy, relatively high level of development of infrastructure and development of the territory [8]

The leading Russian companies have announced largescale investment programs for the development of the AngaraYenisei macroregion. The central site for investment projects of large companies and financial and industrial groups may be considered to be the Yenisei Siberia integrated investment project for joint economic development of three regions: Krasnoyarsk Krai, the Republic of Tyva and Khakassia, which has received the status of a priority project. In 2018 and the early 2019, the investment portfolio of the project increased more than three times up to 1.8 trillion. rbl. According to the Strategy for Spatial Development of the Russian Federation until 2025, one of the main lines of development of the transport infrastructure of the Republic of Tyva is the construction of the Elegest-Kyzyl-Kuragino railway, $402 \mathrm{~km}$ long. The main purpose of the road is the export of coal from the Elegest deposit of up to 15 million tons per year, as well as ore, construction, timber and other cargoes and access to the Trans-Siberian Railway. The project will ensure the development of the mineral resources of the Republic of Tyva with all the ensuing economic effects, the integration of the territories and later - access to China. The development of transport infrastructure, an increase in the throughput capacity of the regional roads will occur simultaneously with the construction of a mining and processing integrated plant, growing production of polymetallic ores, and the development of new gold mining areas.

The largest future regional, interregional and international project for the Republic of Tyva for integration into the transport network of the APR countries is not only the continuation of the Kyzyl-Kuragino railway to Mongolia and China, but also the construction of an international transport corridor (ITC) [9]. The ITC is a transport system that brings together traffic flows (automobile, air, rail), as well as pipelines and telecommunications in the main directions. Today the ITC is acquiring special significance and relevance in terms of developing a cross-border network of international transport corridors. In combination with an information and telecommunication system that allows effective control and management of internal and external traffic flows the ITC will allow the creation of an intelligent multimodal transport 
system (IMTS) [10]. Together with the cognitive information technologies of industrial artificial intelligence, as well as smart cars and highways equipped with smart traffic lights, all kinds of sensors, adaptive road signs, the IMTS can form the basis of a robotic regional transport system [11].

The accelerated and balanced development of the entire transport infrastructure, being one of the priorities of the state policy, is a huge socio-economic incentive for the Republic of Tyva, as it will provide the necessary (but still insufficient) conditions for the development of the innovative component of the economy of the republic, improving the quality of life of the population [1]. Therefore, for the real spatial development of the Republic of Tyva, to ensure coordination of business entities and authorities for accelerated promotion of inter-regional infrastructure projects, to maximize investment attraction, it seems expedient to ensure the creation of a new mechanism of functioning of the territories (investment sites) with a special regime of entrepreneurial activities that takes account of the competitive advantages of the Republic of Tyva, historical and geographical features of both Tyva and the neighboring territories making one macroregion with it. The project will ensure the development of the mineral resources of the Republic of Tyva with all the ensuing economic effects, the integration of the territories and later - access to China.

However, not all the tasks identified in the inter-regional projects are provided with the required investments, appropriate mechanisms of management and implementation of the development policy. At the same time, according to the State Program of the Russian Federation of "Social and Economic Development of the Far East and the Baikal Region" until 2025, the investment portfolio offers just large-scale projects for implementation for a total amount of over nine trillion rublesin the Far East macroregion directly bordering on the Republic of Tyva, which creates clearer prospects for its development compared to the Angara-Yenisei macroregion. Moreover, there is a well-grounded point of view that the existing model of federalism places these neighboring macroregions in an unequal position, since it does not fully take account of the substantial qualitative and quantitative differences of their individual parts when determining the state support measures [2].

It is obvious that the integration of interregional processes should be accompanied by the conditions of economic activity uniform for all entities. Thus, the territorial and structural differentiation of the economies of the regions within Siberia and the Far East is their most obvious characteristics not always, however, taken into account inelaboration of the regional development strategies [3].

The economic potential of the Republic of Tyva as a whole is not lower than the economic potential of many regions of Siberia and the Far East[13], but, nevertheless, Tyva is the most underdeveloped region in Russia. The structure of the economy of the Republic of Tyva is largely determined by the predominance of resource-mining and agro-industrial enterprises forming natural regional clusters. One of the guarantees of the socio-economic development of Tyva is the increasing level of clustering of its economy, especially the agro-industrial complex [4]. It should also be noted that the economy of almost every region of Siberia was historically formed in the form of territorial-production complexes. However, a negative, though inevitable, consequence of clustering in Tyva is also associated with this factor: more than 80 percent of the gross regional product is currently produced on the area accounting for less than 20 percent of its territory. Therefore, the fulfillment of strategic goals, priorities and the solution of the tasks of spatial development of Tyva require significant transformation of production in order to expand and strengthen its entire economic space, without exception of any territory. Since the solution of this issue is impossible without attracting large volumes of investment funds to the macro-region for the implementation of largescale projects, the Tyvan economy urgently needs an influx of investments today, which means a different level of profitability, due to which various types of economic activities in the Republic of Tyva will become attractive to investors in the near future. The state of investment activity in the Republic of Tyva largely predetermines the level of its sociocultural and economic development. One of the main reasons for the lack of investments is that Tyva is one of underdeveloped regions. This significantly reduces the potential in flow of investment resources [12]. Even given the fact that for there cent more than 10 years the Republic of Tyva has been characterized by the trend towards an increase in the investment activity which has led to a 3-fold increase in investment volumes and participation in 8 national projects in 2019 with allocation of funds from the federal budget, the region lacks any expanded fixed capital reproduction [12]. The Republic of Tyva ranks $82^{\text {nd }}$ in the country in terms of investments per person, and in terms of investment volume this indicator is 4.5 times lower than the average one for the Russian Federation.

Since the low investment activity can be overcome by centralized regulatory means, an important parameter for investors influencing the region's competitiveness is the effectiveness of the government support instruments previously proven in a number of priority social and economic development areas (PDA) in the Far East. In general, the differentiated view of the set of the public services necessary for the Republic of Tyva with account for the local specificity of the economy, at least for the process of simple reproduction, has developed quite clearly. In order to offer more attractive products in terms of price and quality to their potential clients manufacturers, especially medium and small enterprises, need financial products related to prompt replenishment of their current assets. In addition, public services should include both financial support and provision of a set of preferences for the implementation of large projects.

Since the underdevelopment of financial markets leads to a shortage of investments in the region, the specific measures of the policy of the state as the regulator of the development of the regional economy include further development of its financial infrastructure, creation of regional financial consortia and every kind of assistance to the corporatization institution, and in the future it is possible to create a macro-regional 
financial exchange. This also involves subsidizing savings and loans, including by attracting investors through the creation of an infrastructure for investing in securities of PDA issuers.

In accordance with Federal Law No. 473 dated December 29, 2014 "On Territories of Priority Socio-Economic Development" which took effect on March 30, 2015, in 3 years PDAs can be created without any geographical restrictions. Contributing to the growth of related types of economic activities the expansion of the PDAs' geography allows diversifying the economy, reducing the dependence of populated localities on township-forming enterprises, increasing the investment attractiveness and creating new jobs, which are factors of subsequent transformation into regional highly competitive clusters and ensuring an increase in the living standard of the local population.

In the future, it may be possible to create a new mechanism in Tyva for the development of investment sites with a special regime for doing business and a new procedure for implementing priority investment projects, as well as a policy of special tax regimes granted to producers in accordance with the promising economic specializations of Tyva which was earlier introduced for the PDA of the Far East, Baikal regions and some single-industry towns of Siberia.

\section{RESEARCH RESULTS}

The socio-economic situation of the region can be improved through specialization of production processes. Specialization in the economic activities of the region is formed under the influence of many objective factors, including its size, availability of natural and labor resources, specific features of historical development, forms of entrepreneurial activities, etc. These factors act as long-term determinants of the direction and speed of transformation of the economy. In addition, Tyva is characterized by the established national configuration of the institutional elements of its economy, which to a certain extent characterizes the structure of its economy, degree of orderliness, and presupposes sufficient stability of institutional interaction in the region.

The choice of specialization in the economic activities for the Republic of Tyva as an underdeveloped region with a minimum of growth opportunities is very limited. The "drivers" of such structural directions of its growth as the development of extractive enterprises based on the dynamic involvement of natural resources in the economic turnover; the creation of innovative mineral processing companies and highly productive agro-industrial clusters are identified in the context of the competitive advantages noted in the Strategy for Spatial Development of Regions of the RF. The growth points include the construction of the Elegest-Kyzyl-Kuragino railway line, the formation of a motor transport infrastructure, and the development of the mineral resource base.

It is indisputable that the spreading of all effective tools for the development of the economy and the socio-cultural spherein the Republic of Tyva which have worked mainly in the Far East and some Siberian regions in the recent years would allow the transition from raw materials export to an innovative socially oriented type of economic development. However, the availability of the favorable investment climate alone cannot guarantee balanced and sustainable economic growth ensuring achievement of human potential, reducing the differences within the region in the level and quality of life of the population.

In the authors' opinion, the reasons for the simultaneous combination of the action of various factors in the formation of spatial development trends in Tyva are as follows.

Firstly, as the types of the economic activities determining the competitive advantages expand, the wages of the people employed in them also grow. Consequently, the existing gap in the qualifications and wages can lead to a gradual flow of labor into competitive rapidly developing enterprises from agriculture limited in its socio-economic development, where the supply of production factors is limited for natural reasons. As a rulehuman capital is concentrated in those areas of activity that bring the maximum benefit to the individual. This concentration can be associated with only two reasons: high wages in economically important industries, the creation of comfortable working conditions and / or the social popularity of the industry [13]. It is quite understandable that the population will give preference to areas of activities with higher wages, such as, for example, transport logistics, construction, development of new deposits and others, in which, according to estimates, about 10 thousand new jobs will be created in Tyva [14]. According to the authors, given the future needs of transport logistics, road industry and services, the number of new workers may double compared to the above, which is equivalent to about a third of the number of the people currently employed in agriculture in Tyva. Therefore, a fundamentally significant barrier to spatial development, among other primary ones, may appear to be the depopulation of rural residents who account for almost half of the total population of the republic today. Despite the fact that one of the current specific features of the republic is the extremely nonuniform distribution of the population, the prospective concentration of the population near growth points due to depopulation of the rural population may cause degradation of rural populated localities, disrupt the efficient functioning of the agroindustrial sector and the food security of the republic through the production of locally manufactured food products [15]. With the destabilization of the demographic situation in rural areas causing a decrease in the human capital and a shortage of labor resources of the necessary qualification, it is impossible to efficiently use the land and other natural resources, create economic conditions for expanded reproduction in agriculture.

Secondly, the construction of the ITC and, subsequently, the IMTS to access the transit corridors from Europe to the APR countries is certain to attain the competitive advantages of Tyva in transforming it from a transport dead end into an international transport corridor due to the use of its geographical location as a natural "bridge" between Europe and the APR countries. With the launch of projects to enter the international transport corridors, the expansion of transport and logistics flows and the development of new deposits, the revenues in the budget of Tyva are projected to increase about 3 times in the future 5-7 years up to 30 billion rubles [14]. At 
the same time, a part of Tyva territory located mainly outside the main populated area, not included in the growth points, will remain a territory with low transport and communication development and a low level of development of energy infrastructure, and, therefore, will be still characterized by investment unattractiveness. In combination with the insufficient level of development of entrepreneurship, labor resources, the production factors located there will keep declining steadily. This primarily concerns the agricultural sector of the republic with regard to its aggravating crisis [15]. The way out of this situation is the organization of entrepreneurial activities through the creation of ethnic clusters in the Republic of Tyva [16].

Thirdly, the territorial nonuniformity of the expected growth within Tyva and the prospects of a shift in the employment structure may lead to gradual spatial polarization of development, which will force to increase the inefficient budget expenditures to maintain the social infrastructure of the territories that become economically semi-desolate, lack competitive advantages and are not attractive to investors.

\section{CONCLUSION}

The spatial development of the region is determined on the basis of the analysis of many factors both within the region itself and in the country and in the outside world. Based on competitive advantages, the new spatial development strategy of Russia determines the promising economic specializations, growth points, for every region. However, the necessary regulatory measures for development of the region, in and of themselves, are not a determining factor of investment attractiveness. To increase the efficiency of the investment process, the Republic of Tyva needs a systemic nature of the process. The systemic investment process is ensured by a certain combination of fiscal and monetary policy measures with account of its parameters and positioning in the interregional system of specialization, as well as with account of the phase of the national economy cycle, formal measures of legislative regulation of social development processes and other factors expressing the technical and economic development paradigm. Hence, the systemic process of creating an attractive environment for the investor needs greater participation of government structures, including through indirect methods that complement the previously mentioned specific measures. Indirect methods implement the function of the state as coordinator acting along with regional development institutions.

In the contemporary world, special development institutions exist both in foreign countries [6, 7] and in Russia, in particular in Siberia and the Far East. Their activities are aimed at improving the investment climate in a particular region; they also act as institutions of innovative development. In the format of the program of investment attractiveness, the development institutions are engaged in simplifying the investment process, stimulating innovation, and assisting in the construction of the infrastructure for investors, including through information technologies and electronic services. Problems of coordination of socio-economic growth exist in the development of any region. However, today the Republic of Tyva, as the most underdeveloped region in the country, is especially in need of some part of the coordination function, as defined here, to be delegated by the state to regional and macroregional development institutions.In general, the new vision of the role of the state in the context of the formation of new institutions complements the hierarchy of structures for coordinated development: the top level is the Government of the Russian Federation which identifies the tasks, principles, priorities and main areas of spatial development of Russia, promising growth centers and promising specializations of the constituent entities of the Federation; then the macro-regional institutional level, with the institutions coordinating investment development in the macro-region and financial instruments (for example, creation of the Angara-Yenisei Bank, a financial exchange in the future); regional institutional level (stock development tools, stock exchanges that can accumulate and redistribute investment resources in the regional economic system); at the regional administrative level these are the relevant administrative services of the Republic of Tyva as a subject of the Federation and at the regional public level is the most dynamic environment in the form of public institutions that coordinate the historical and ethnographic features of the territory and the socio-economic development of the region.

The authors approaches to a new vision of the governance role as coordinator and regulator is capable of providing the potential for structural transformation of underdeveloped region, taking into account the characteristics of its site and long-term national interests. It also concerns the search for ways to overcome both real and potential depression, territories, analysis of the possibilities of specialization of regions of foreign countries, primarily the border regions of Mongolia and China, in determining various forms of support, developing regional policy of the country, assessing the possibilities of eliminating sharp differences in socioeconomic development and conditions for the sustainable functioning of the regional economy.

\section{ACKNOWLEDGMENT}

The work was performed with the financial support of the grants of the Russian Foundation for Basic Research No. 18410-170002 p_a and the Government of the Republic of Tyva.

\section{REFERENCES}

[1] V. K. Sevek, K. B. Sagaan-ool, and A. M. Oorzhak, "Analiz transportnoi infrastruktury Respubliki Tyva", Scientific Review: Theory and Practice, 2017, no. 11, pp. 72-81 (in Russian).

[2] A. N. Asaul and B. A. Dongak, "Prioritet nyenapravleniia klasternoi organizatsii predprinimatel'skoi deiatel'nosti Respubliki Tyva", Basic research, 2014, no. 11-2, pp. 377-382 (in Russian); N. V. Zubarevich "Strategiya prostranstvennogo razvitiya: prioritety I instrumenty", Economic Issues 2019, no. 1, pp. 135-145.

[3] M. A. Asaul, "Sozdanie novykh transportnykh marshrutov mezhdu Evropoi I Aziei", Mirovoe innovatsionnoe sorevnovanie, Rol' i mesto Rossii v nem: materialy XVIII nauchno-prakticheskoi konferentsii, St. Petersburg: Izd-vo ANO «IPEV», 2016, pp. 434-442 (in Russian); G. F. Balakina, "Specifics of formuling a regional socioeconomic development strategy in the context of modernization", Regional Research of Russia, 2015, T. 5, no, 3, pp. 270-275 (in English). 
[11] I. G. Malygin, V. I. Komashinskii, N. V. Shatalova, and others "Kognitivnaia ekonomika i transport", Tekhnologii postroeniia kognitivnykh transportnykh system Materialy vserossiiskoi nauchnopraktiches koikonferentsii, FGBUN Institut problem transportaim, N.S. Solomenko Rossiiskoiakademiinauk, 2018, pp. 21-29 (in Russian).

[12] A. N. Asaul and B. A. Dongak, "Prioritetnye napravleniia klasternoi organizatsii predprinimatel'skoi deiatel'nosti Respubliki Tyva", Basic research, 2014, no. 11-2, pp. 377-382 (in Russian).

[13] R. A. Kamaev, Yu. A. Levin, and M. A. Sokolnikov, "Formirovanie tekhnologicheskih ukladov $\mathrm{V}$ tekstilnoj promyshlennosti: proizvodstvennye I regionalnye aspekty", Proceedings of higher educational institutions, Technology of textile industry 2019, no. 1(379), pp. 5-11 (in Russian).

[14] S. V. Pale, "Torgovo-transportnye perspektivy Rossii I Azii", Southeast Asia: Current Development Issues, 2018, vol.1, no. 2 (39), pp. 35-39 (in Russian).

[15] D. F. Dabiev and U. M. Dabieva, "Problemy I perspektivy razvitiia sel'skogokhoziaistva Tuvy", Problems of the modern economy, 2015, no. 3 (55), pp. 280-282 (in Russian).

[16] B. A. Dongak, "Organizatsiia predprinimatel'skoi deiatel'nosti posredstvom sozdaniia etnoklasterov v Respublike Tyva", Dissertatsiia na soiskanie uch. stepeni kand. ekon. nauk, St. Petersburg universitet ekonomiki I finansov, 2015, 159 p., 107 p. (in Russian). Rossii v nem: materialy XVIII nauchno-prakticheskoi konferentsii, St. Petersburg: Izd-vo ANO «IPEV», 2016, pp. 434-442 (in Russian). 